\title{
Intravenous lipid infusion affects dry matter intake, methane yield, and rumen bacteria structure in late-lactating Holstein cows
}

\author{
Ole Lamp, ${ }^{*} \dagger$ Henry Reyer,‡ Winfried Otten,§ Gerd Nürnberg,\# Michael Derno, ${ }^{*}$ Klaus Wimmers, $\ddagger l l$ \\ Cornelia C. Metges, ${ }^{*}$ and Björn Kuhla*1 \\ *Institute of Nutritional Physiology "Oskar Kellner," Leibniz Institute for Farm Animal Biology (FBN), Wilhelm-Stahl-Allee 2, 18196 Dummerstorf, \\ Germany \\ †Schleswig-Holstein Chamber of Agriculture, Training and Research Center Futterkamp, 24327 Blekendorf, Germany \\ †lnstitute of Genome Biology, \\ §Institute of Behavioral Physiology, and \\ \#Institute of Genetics and Biometry, Leibniz Institute for Farm Animal Biology (FBN), Wilhelm-Stahl-Allee 2, 18196 Dummerstorf, Germany \\ IIFaculty of Agricultural and Environmental Sciences, University Rostock, 18059 Rostock, Germany
}

\begin{abstract}
Increasing the dietary fat content of ruminant diets decreases methane $\left(\mathrm{CH}_{4}\right)$ production. This effect is caused by the toxic properties of fatty acids on rumen microbial populations, coating of feed particles diminishing the accessibility for microbes, and a reduction in dry matter intake (DMI). The latter effect is caused by postabsorptive long-chain fatty acids eliciting anorexic signaling; however, whether circulating long-chain fatty acids affect rumen $\mathrm{CH}_{4}$ production alike is unknown. To approach this question, 5 rumen-cannulated Holstein cows in late lactation received 2 jugular catheters and were kept in respiration chambers to measure $\mathrm{CH}_{4}$ production and DMI for $48 \mathrm{~h}$. In a crossover design, cows were intravenously infused with a $20 \%$ lipid emulsion (LIPO) or $0.9 \% \mathrm{NaCl}(\mathrm{CON})$. The LIPO cows received $2.1 \mathrm{~kg}$ of triglycerides $/ \mathrm{d}[0.152 \pm 0.007 \mathrm{~g}$ of triglycerides $\left./(\mathrm{kg} \text { of } \mathrm{BW} \times \mathrm{h})^{-1}\right]$ consisting of $12.1 \%$ palmitic acid, $4.2 \%$ stearic acid, $31.1 \%$ oleic acid, and $52.7 \%$ linoleic acid. Blood and rumen fluid samples were taken hourly during the day. Results showed that LIPO compared with CON infusion increased plasma triglyceride as well as free fatty acid and serotonin concentrations but reduced the proportion of de novo synthesized milk fatty acids (sum of C6 to C16). Daily $\mathrm{CH}_{4}$ production and DMI were lower, whereas daily $\mathrm{CH}_{4}$ yield $\left(\mathrm{CH}_{4} / \mathrm{DMI}\right)$ was greater in LIPO than $\mathrm{CON}$ cows, although $\mathrm{CH}_{4}$ yield decreased from d 1 to $\mathrm{d} 2$ by 2 to $14 \%$ in LIPO-infused cows only. This effect was as-
\end{abstract}

Received November 6, 2017.

Accepted February 21, 2018.

${ }^{1}$ Corresponding author: b.kuhla@fbn-dummerstorf.de sociated with a higher (acetate + butyrate)/propionate ratio, tending lower propionate concentrations between 24 and $34 \mathrm{~h}$ of infusion, reduced relative abundances of genera belonging to Succinivibrio, Ruminococcaceae, and Ruminiclostridium, and greater relative Bacteroidetes genus abundances in the rumen.

Key words: lipid infusion, milk fat synthesis, methane, microbiome, dairy cow

\section{INTRODUCTION}

Daily methane $\left(\mathrm{CH}_{4}\right)$ production from lactating dairy cows was shown to be directly related to the concentration of de novo-synthesized milk fatty acids (individual or the sum of C8:0, C10:0, C12:0, C14:0, and C16:0) but negatively related to $\mathrm{C} 18$ milk fatty acids (individual or the sum of $\mathrm{C} 18$, the sum of $\mathrm{C} 18: 1$ trans, or the sum of C18:1 cis; Chilliard et al., 2009). Dietary supplementation with oilseeds rich in C18 UFA such as different linseed products, cottonseeds, or canola oilseeds increased total $\mathrm{C} 18$ but reduced $\mathrm{C} 6$ to $\mathrm{C} 16$ fatty acid contents in milk while diminishing enteric $\mathrm{CH}_{4}$ production (Johnson et al., 2002; Martin et al., 2008; Chilliard et al., 2009). The reduction of enteric $\mathrm{CH}_{4}$ production in response to dietary oilseeds is due to decreased accessibility of feed particles for microbes, direct toxic effects on microbial populations primarily on protozoa, and a reduction in DMI (Machmüller and Kreuzer, 1999; Chilliard et al., 2009). Apart from the dietary effects on microbes, circulating long-chain fatty acids may disturb the intestinal barrier integrity and affect bacterial composition in the lumen (Hodin et al., 2012; Harris et al., 2014; Lavallee et al., 2016), suggesting that $\mathrm{CH}_{4}$ production may also be influenced by systemic fatty acids of the host. Furthermore, circulating long-chain fatty acids can be sensed by enterocytes or the liver to signal satiety (Leonhardt and Langhans, 
2004), suggesting that the long-chain fatty acid-induced decline in DMI and the accompanying reduction in $\mathrm{CH}_{4}$ production may also be influenced by fatty acid metabolism of the host, although intravenously infused lipids may not affect DMI of dairy cows (Stocks and Allen, 2014).

During the course of lactation, DMI increases from early to peak lactation and slowly declines afterward, and $\mathrm{CH}_{4}$ production of cows in second or higher lactation usually follows the course of DMI (Garnsworthy et al., 2012). As first lactating cows still grow, daily $\mathrm{CH}_{4}$ production increases from early (e.g., wk 5) to peak (e.g., wk 13) to late (e.g., wk 42) lactation, at least when cows are fed the same diet throughout the entire lactation period (Bielak et al., 2016). However, all high-yielding dairy cows mobilize endogenous fatty acids from adipose tissue in the early lactation period, thereby increasing the amount of C18:0 secreted with milk (Lerch et al., 2015). In late lactation, endogenous long-chain fatty acids are less mobilized and therefore used only to a marginal extent for milk fat synthesis (Lerch et al., 2015), underlining that the inverse relationship between the sum of C18 milk fatty acids and $\mathrm{CH}_{4}$ production is valid for different stages of lactation and independent of dietary fat supplementation (Chilliard et al., 2009). Also, $\mathrm{CH}_{4}$ yield $\left(\mathrm{CH}_{4} / \mathrm{DMI}\right)$ in early but not late lactation was found to be lower in cows that mobilized high fat compared with less fat (Bielak et al., 2016). The plasma concentration of long-chain fatty acids including C18:0 reflects the extent of fat mobilization and was found to be directly related to C18:0 milk fatty acids (MFA; Lerch et al., 2015). It has been proposed that circulating long-chain fatty acids affect rumen-intestinal motility, which in turn could influence the retention time of the digesta in the rumen and, consequently, $\mathrm{CH}_{4}$ yield; however, this assumption was deduced only from an association study (Bielak et al., 2016). Various rumen-intestinal hormones and neurotransmitters such as ghrelin, cholecystokinin, and serotonin are involved in the regulation of rumen motility, and their release from entero- and neuroendocrine cells is closely related to long-chain fatty acid metabolism (Plaza et al., 1996; Börner et al., 2013b; Bielak et al., 2016). Therefore, the aim of the present study was to test the hypothesis of whether increased systemic lipid levels rich in $\mathrm{C} 18$ fatty acids reduce $\mathrm{CH}_{4}$ production and $\mathrm{CH}_{4}$ yield from dairy cows and whether this effect is accompanied by changes in the rumen microbial community composition. This hypothesis was tested by an intravenous infusion of C18-rich triglycerides (TG), which are converted in vivo by lipases forming free C18 fatty acids.

\section{MATERIALS AND METHODS}

\section{Animals, Experimental Design, and Infusions}

The experimental protocol was approved by the local animal ethics committee (Landesamt für Landwirtschaft, Lebensmittelsicherheit und Fischerei Mecklenburg-Vorpommern; approval no. 7221.3-1-056/13). Six rumen-fistulated German Holstein cows were randomly assigned to a crossover design with 2 infusions per cow in 3 blocks. One cow suffered from fever during the second infusion and was removed from the trial and data evaluation. The remaining 5 cows ( 4 in second lactation and 1 in third lactation) were between 270 and 310 DIM and had a BW between 515 and 667 $\mathrm{kg}$. Infusions consisted of 48-h intravenous infusions of either $0.9 \% \mathrm{NaCl}$ (B. Braun, Melsungen, Germany; CON) or a long-chain TG emulsion (Intralipid, Fresenius Kabi, Bad Homburg, Germany, or Lipofundin N, B. Braun; LIPO), both containing $20.0 \%$ soybean oil, $1.2 \%$ egg lecithin, $2.5 \%$ glycerol, and $76.3 \%$ water) to elevate plasma nonesterified fatty acids (NEFA). The fatty acid composition of LIPO was $12.1 \%$ palmitic acid (C16:0), 4.2\% stearic acid (C18:0), 31.1\% oleic acid (C18:1 cis-9), and 52.7\% linoleic acid (C18:2 cis-9,cis-12) as determined by GC-MS (see below). Infusions were administered to the right jugular vein via a peristaltic pump at a targeted rate of $7.4 \mathrm{~mL} /$ min for $\mathrm{NaCl}$ and LIPO. Each cow received $2.1 \mathrm{~kg}$ of $\mathrm{TG} / \mathrm{d}$ intravenously $[0.152 \pm 0.007 \mathrm{~g}$ of TG $/(\mathrm{kg}$ of BW $\left.\times \mathrm{h})^{-1}\right]$. A washout of at least $4 \mathrm{~d}(4-10 \mathrm{~d})$ between 2 treatments prevented carryover effects because plasma NEFA concentrations declined to basal level within 24 $\mathrm{h}$ after the end of infusion and DMI returned to the preinfusion period level within $48 \mathrm{~h}$. Four days before the first treatment and during the washout phase, cows were kept in tiestalls at $15^{\circ} \mathrm{C}$ with ad libitum feeding.

\section{Measurements and Sample Collections}

Twenty hours before initiation of infusion, animals were equipped with indwelling catheters (Certofix mono; B. Braun) inserted in the right and left jugular veins. Patency of the catheters was maintained by flushing with $5 \mathrm{~mL}$ of heparinized saline $(10 \mathrm{IU} / \mathrm{mL})$ before and between blood samplings. The BW was measured and animals in pairs of 2 (1 CON and 1 LIPO) were transferred to 2 adjacent open-circuit respiration chambers (each with a $\mathrm{CO}_{2}$ recovery of $99.9 \%$ ) separated by a window through which the animals could see each other (Derno et al., 2013). A light cycled on from 0600 to $1900 \mathrm{~h}$. The airflow through the chamber was approximately $30 \mathrm{~m}^{3} / \mathrm{h}$ and was measured by a differ- 
Germany) for the analyses of milk fat, protein, lactose, and urea using infrared spectrophotometry (MilkoScan; Foss GmbH, Rellingen, Germany) to calculate ECM yield as follows:

$$
\begin{gathered}
\operatorname{ECM}(\mathrm{kg})=[0.038 \times \text { fat }(\mathrm{g})+0.024 \times \text { protein }(\mathrm{g}) \\
+0.017 \times \text { lactose }(\mathrm{g})] \times \text { milk }(\mathrm{kg}) / 3.14
\end{gathered}
$$

\section{Chemical Analyses}

Feed samples were dried at $60^{\circ} \mathrm{C}$ for $72 \mathrm{~h}$ and ground through a 1-mm screen. Dry matter weight was calculated after drying samples at $110^{\circ} \mathrm{C}$ overnight. Samples were analyzed for $\mathrm{CP}(6.25 \mathrm{~N}$; FP-428 nitrogen determinator; Leco, St. Joseph, MI), NDF, ADF and ADL (Ankom filter bag technique; Ankom, Macedon, NY), crude fat (petrol ether extraction), starch and sugar (polarimetric), and ash after heating to $550^{\circ} \mathrm{C}$ according to Naumann and Bassler (2006).

Plasma NEFA, TG, glucose, and BHB concentrations were analyzed photometrically (Abx Pentra 400; Horiba, Kyoto, Japan) using kit NEFA-HR(2) (Wako Chemicals, Neuss, Germany) for NEFA, no. A11A01640 (Horiba) for TG, no. RB 1008 (Labor+Technik Lehmann, Berlin, Germany) for BHB, and no. A11A01667 (Axon Lab, Reichenbach, Germany) for glucose. Plasma serotonin concentrations were determined in duplicate after protein precipitation on an HPLC system (Shimadzu Deutschland GmbH, Duisburg, Germany). Protein precipitation was achieved by adding $25 \mu \mathrm{L}$ of $2 M$ perchloric acid to $250 \mu \mathrm{L}$ of plasma. Samples were shaken for $30 \mathrm{~s}$, incubated for $5 \mathrm{~min}$ on ice, and centrifuged 2 times at $37,000 \times g$ for $10 \mathrm{~min}$ at $4^{\circ} \mathrm{C}$. Supernatants were filtered using $0.2-\mu \mathrm{m}$ polytetrafluoroethylene filters (Millex-LG, Millipore, Darmstadt, Germany) and injected directly into the HPLC system. Serotonin was analyzed with fluorescence detection as described recently (Stracke et al., 2017). Plasma acetate concentrations were determined as chloroethyl ester derivative on a GC-flame ionization detector instrument (Series 2010, Shimadzu Corp., Kyoto, Japan) on a 25-m RTX-1701 column according to Kristensen et al. (2000). Due to spoilage of the rumen samples from 1 cow, the analyses could be performed for only 4 cows. Rumen fluid short-chain fatty acid concentrations were measured using a GC equipped with a flame ionization detector (Series 20, Shimadzu Corp.) and a 25-m free fatty acid phase column according to Ryan (1980). Milk fatty acids were analyzed as described previously (Börner et al., 2013a) as methyl ester derivatives on an HP-Ultra 2 column ( $50 \mathrm{~m}, 0.32$ i.d.; $0.52 \mu \mathrm{m}$ ) by GCcoupled MS (GC-MS-QP2010, Shimadzu Corp.).

\section{S rRNA Profiling}

As the rumen fluid pellets from 1 cow spoiled, DNA could be obtained from only 4 LIPO and corresponding CON animals for 3 time points $(0,24$, and $48 \mathrm{~h}$ relative to initiation of infusion; 24 samples total) using the PowerLyzer PowerSoil DNA isolation kit (MoBio, Carlsbad, CA). The procedure followed the manufacture's recommendations with additional incubation steps for $10 \mathrm{~min}$ at $70^{\circ} \mathrm{C}$ and $10 \mathrm{~min}$ at $95^{\circ} \mathrm{C}$ before beating. Based on purified DNA, the hypervariable region V4 of the $16 \mathrm{~S}$ rRNA gene was amplified using specific primer $515^{\prime} \mathrm{F}$ and $806 \mathrm{R}$ including adapters and barcodes (Kozich et al., 2013; Hugerth et al., 2014). Polymerase chain reaction was carried out in duplicate with an initial denaturation at $95^{\circ} \mathrm{C}$ for $2 \mathrm{~min}$, followed by 30 cycles at $95^{\circ} \mathrm{C}$ for $30 \mathrm{~s}, 55^{\circ} \mathrm{C}$ for $60 \mathrm{~s}$, and $72^{\circ} \mathrm{C}$ for $90 \mathrm{~s}$, and a final extension for $10 \mathrm{~min}$ at $72^{\circ} \mathrm{C}$ using the 5 Prime HotMasterMix (5 Prime, Hamburg, Germany). Duplicates were combined and purified using magnetic beads (Agencourt AMPure XP, Beckman Coulter, Krefeld, Germany). All PCR products were mixed equimolarily and sequenced on a HiSeq2500 (Illumina, San Diego, CA) generating 250-bp paired-end reads. Raw data were filtered, trimmed, and analyzed using mothur software (version 1.37.4; Schloss et al., 2009). Sequences were globally aligned to the Silva reference database (release 123; https://www.arb-silva.de/, accessed May 13, 2016). Putative chimeric sequences were removed using Uchime (Edgar et al., 2011). Sequences were clustered into operational taxonomic units considering a sequence identity of $\geq 97 \%$. Taxonomic annotations for operational taxonomic units were retrieved from the Silva database (release 123).

\section{Statistical Analyses}

Repeated measures data were analyzed for the effects of infusion (LIPO or CON), time (0-10, 24-36, and 48 h), order of infusion (LIPO first and $\mathrm{NaCl}$ second, or vice versa), and their interactions as a completely randomized design using PROC MIXED with a repeated measurements analysis with treatment and infusion time as the repeated effects (SAS Institute, Cary, NC). We did not consider the block effect (animals tested at the same time) in our statistical model because 1 of the 6 animals was removed from the trial so that only 2 pairs of cows remained, which is too few for a reliable estimate of this effect. To evaluate the effect of period, means of hourly plasma and rumen metabolite values from 0 to $24 \mathrm{~h} \mathrm{(d} \mathrm{1)} \mathrm{and} 25$ to $48 \mathrm{~h} \mathrm{(d} \mathrm{2)} \mathrm{were} \mathrm{calcu-}$ lated, and the effects of period (d 1 and 2), infusion, order of infusion, and their interactions with treatment 
and period as repeated effects were tested accordingly (Supplemental Table S1; https://doi.org/10.3168/jds .2017-14101). The covariance structure for data on milk yield and constituents, gases, DMI, and rumen and plasma metabolites was modeled as unstructured for treatment factor and as autoregressive or compound symmetry for time effect. For statistical comparison of $16 \mathrm{~S}$ rRNA profiles between LIPO and CON cows, analysis of count data was carried out with the DESeq2 package using the negative binominal Wald test (Love et al., 2014). To exclude taxa with very low abundance, observations with fewer than 5 read counts in at least 10 samples were discarded. The design used for DESeq2 considered treatment as a fixed effect while controlling for the effects of animal and time. $P$-values were adjusted for multiple testing following the BenjaminiHochberg method, and differences were considered significant at an adjusted $P$-value of $<0.05$.

\section{RESULTS}

\section{Plasma, Rumen, and Milk Metabolites}

The LIPO but not CON infusion increased plasma TG and NEFA during the first day of infusion $\left(P_{\text {infusion }}\right.$ $\leq 0.01)$ with increased infusion time $\left(P_{\text {infusion }} \times\right.$ time $<0.01$; Figure 1a and b). During h 24 to 34 and after the 48-h infusion period, plasma TG and NEFA concentrations were $\left(P_{\text {infusion }} \leq 0.01\right)$ or tended to be $\left(P_{\text {infusion }}<0.10\right)$ higher in LIPO cows than CON cows. There was no LIPO effect on plasma glucose and BHB concentrations, but plasma BHB increased during d $2\left(P_{\text {time }}<0.01\right)$, whereas glucose was unaltered on $\mathrm{d}$ 1 and changed with time on d 2 of infusion $\left(P_{\text {time }}<\right.$ 0.05) in both groups (Figure 1c and d). Plasma acetate concentrations did not change during the first day of infusion but were greater in CON cows than in LIPO cows during d 2 and after $48 \mathrm{~h}$ of infusion $\left(P_{\text {infusion }} \leq\right.$ 0.05; Figure 1e).

Rumen acetate was not affected by infusion, but rumen propionate tended to be lower during LIPO treatment compared with CON treatment on both days of infusion $\left(P_{\text {infusion }}<0.10\right.$; Figure $2 \mathrm{a}$ and $\left.\mathrm{b}\right)$. Rumen butyrate tended to be lower on d 1 but not on $\mathrm{d} 2$ in LIPO-infused cows $\left(P_{\text {infusion }}<0.10\right)$ and tended to vary over time during d 2 only $\left(P_{\text {time }}<0.1\right.$; Figure $\left.2 \mathrm{c}\right)$. Accordingly, the rumen (acetate + butyrate)/propionate ratio was greater in LIPO cows than in CON cows on $\mathrm{d}$ $2\left(P_{\text {infusion }}<0.05\right)$ but not on $\mathrm{d} 1$ and at $48 \mathrm{~h}$ of infusion (Figure 2d). However, none of the mean plasma und rumen metabolite concentrations changed from $\mathrm{d} 1$ to d 2 of infusion $\left(P_{\text {period }}>0.1\right.$; Supplemental Table S1, https://doi.org/10.3168/jds.2017-14101).
There was no change in milk yield, lactose, or milk protein concentrations between CON and LIPO infusions, but milk urea concentrations were higher and milk protein concentrations tended to be lower in LIPO cows $\left(P_{\text {infusion }}=0.03\right.$ and 0.07 , respectively; Table 2). Milk fat content, milk fat yield, and milk urea concentration increased with progressing time of LIPO infusion $\left(P_{\text {infusion } \times \text { time }} \leq 0.01\right)$, whereas ECM tended to decrease over time in CON cows only $\left(P_{\text {infusion } \times \text { time }}=0.06\right)$. Both concentration and yield of de novo-synthesized MFA (sum of C6:0, C8:0, C10:0, C12:0, C14:0, C14:1 cis9, C16:0, and C16:1 cis-9) was reduced, whereas the sum of $\mathrm{C} 16$ and C18 MFA increased in LIPO cows but not CON cows $\left(P_{\text {infusion }}<0.01\right)$ at both days of infusion (Table 2). Specifically, levels of C18:2 cis-9,cis-12 and the sum of C18:1 cis, which are also present in both lipid emulsions, were 9-fold or tended to be 1.1fold greater $\left(P_{\text {infusion }}<0.01\right.$ and $=0.07$, respectively $)$, whereas C18:0 and the sum of C18:1 trans in milk fat was or tended be 0.6- to 0.4 -fold lower $\left(P_{\text {infusion }}<0.01\right.$ and $=0.06$, respectively) in LIPO relative to CON animals (Table 2).

\section{DMI, $\mathrm{CH}_{4}$ Production, and Metabolic Oxidation}

The amount of DMI on the day before transfer to the chamber did not differ between LIPO and CON cows $\left(14.9 \pm 0.5 \mathrm{~kg}\right.$ and $15.0 \pm 0.5 \mathrm{~kg}$, respectively; $P_{\text {infusion }}$ $\left.=0.78 ; P_{\text {order }}=0.31\right)$. In the 12 -h nocturnal preinfusion period, DMI amounted to $3.3 \pm 0.5 \mathrm{~kg}$ for $\mathrm{CON}$ and $3.8 \pm 0.5 \mathrm{~kg}$ for LIPO cows and was not different between treatments $\left(P_{\text {infusion }}=0.39 ; P_{\text {order }}=0.60\right)$. Also, $\mathrm{CH}_{4}$ production, DMI, and $\mathrm{CH}_{4}$ yield were not different between CON and LIPO cows within the 12-h interval before the start of infusion (data not shown). The LIPO treatment but not the CON treatment reduced DMI $\left(P_{\text {infusion }}<0.01 ;\right.$ Figure $\left.3 \mathrm{a}\right)$, which was associated with a shorter daily eating time in LIPO compared with CON animals $\left(P_{\text {infusion }}=0.02\right.$; Figure $3 \mathrm{~b}$ ), whereas the number of meals per day and the intermeal interval were not affected (data not shown). When expressed on a gross energy basis, LIPO cows ingested 54.4 and 49.3 MJ less than CON cows on d 1 and d 2, respectively, whereas LIPO infusion provided $84 \mathrm{MJ} / \mathrm{d}$. According to the reduction in DMI, $\mathrm{CH}_{4}$ production was lower in LIPO cows than in CON cows $\left(P_{\text {infusion }}=0.01\right)$ and was not different between $\mathrm{d} 1$ and 2 of infusion $\left(P_{\text {time }}=\right.$ 0.93; Figure 3c). The $\mathrm{CH}_{4}$ emission normalized to ECM was lower in LIPO-infused animals $\left(P_{\text {infusion }}=0.02\right.$; Figure $3 \mathrm{~d}$ ). When $\mathrm{CH}_{4}$ production on $\mathrm{d} 1$ was divided by DMI on $\mathrm{d} 1$ (and when $\mathrm{CH}_{4}$ production on $\mathrm{d} 2$ was divided by DMI on d 2), there was an overall effect of LIPO infusion on $\mathrm{CH}_{4}$ yield $\left(P_{\text {infusion }}=0.03\right)$. However, 

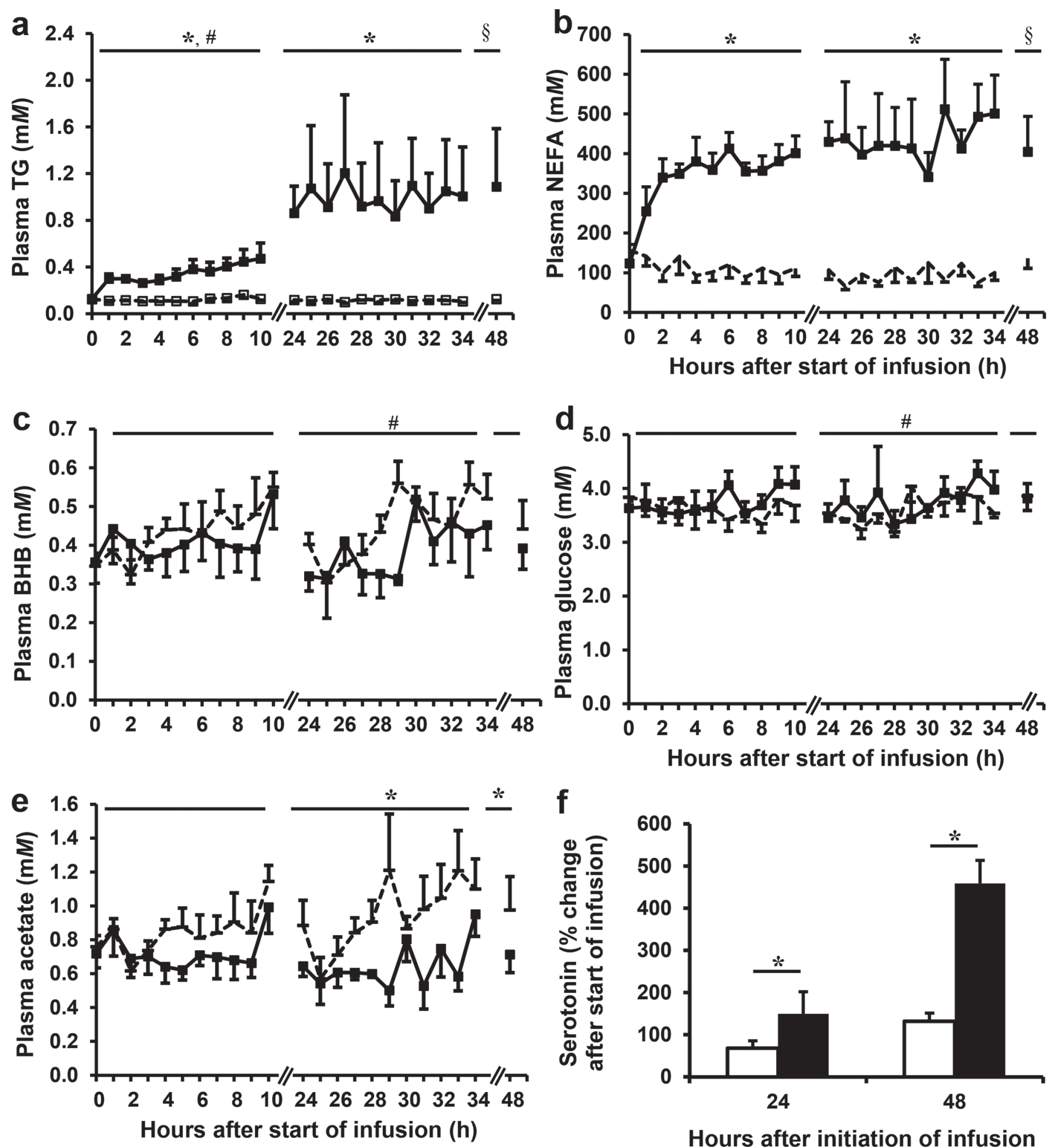

Figure 1. Plasma (a) triglyceride (TG), (b) nonesterified fatty acid (NEFA), (c) BHB, (d) glucose, and (e) acetate (each $\mathrm{n}=5)$ and (f) percentage change of serotonin $(\mathrm{n}=4)$ concentrations of cows intravenously infused with lipofundin (LIPO, $\mathbf{\square})$ or saline (CON, $\square)$ for 48 h. Data are shown as mean $\pm \mathrm{SE}$. For each time interval, ${ }^{*}$ indicates $P_{\text {infusion }} \leq 0.05, \S$ indicates $P_{\text {infusion }} \leq 0.10$, and \# indicates $P_{\text {time }} \leq 0.05$ (ANOVA). $P$-values for infusion $\times$ time, order, infusion $\times$ order time $\times$ order, and infusion $\times$ time $\times$ order are presented in Supplemental Table S2 (https: $/$ doi.org/10.3168/jds.2017-14101). 
because $\mathrm{CH}_{4}$ yield of LIPO-infused cows decreased from d 1 to $\mathrm{d} 2$ on average by $8 \%(2-14 \%), \mathrm{CH}_{4} / \mathrm{DMI}$ was significantly greater on d $1(P<0.05$, Tukey-Kramer $)$ but not on d $2(P=0.63$, Tukey-Kramer $)$ with LIPO infusion (Figure 3e).

Because part of the $\mathrm{CH}_{4}$ production measured originates from feed intake of the preceding day, we also calculated $\mathrm{CH}_{4}$ yield from $\mathrm{CH}_{4}$ production on $\mathrm{d} 2$ (24-48 h) divided by DMI ingested on d 1 (0-24 h) of infusion, thereby accounting for a $24 \mathrm{~h}$-delay between $\mathrm{CH}_{4}$ production and the preceding DMI. The resulting 24-h offset $\mathrm{CH}_{4}$ yield differed between LIPO and CON cows $\left(P_{\text {infusion }}=0.03\right.$; Figure $\left.3 \mathrm{f}\right)$ and was intermediate to the $\mathrm{CH}_{4}$ yield calculated from $\mathrm{CH}_{4}$ production and DMI on d 1 and d 2, respectively (Figure 3e). In contrast, it remained constant in CON cows, indicating that the high $\mathrm{CH}_{4}$ yield on $\mathrm{d} 1$ of LIPO cows is affected by feed consumed within the 24-h preinfusion period.

Although $\mathrm{CH}_{4}$ production and $\mathrm{CH}_{4}$ yield were different in LIPO and CON cows, there was no change in the composition of the most abundant phyla between treatments (Figure 4). However, slight alterations in a

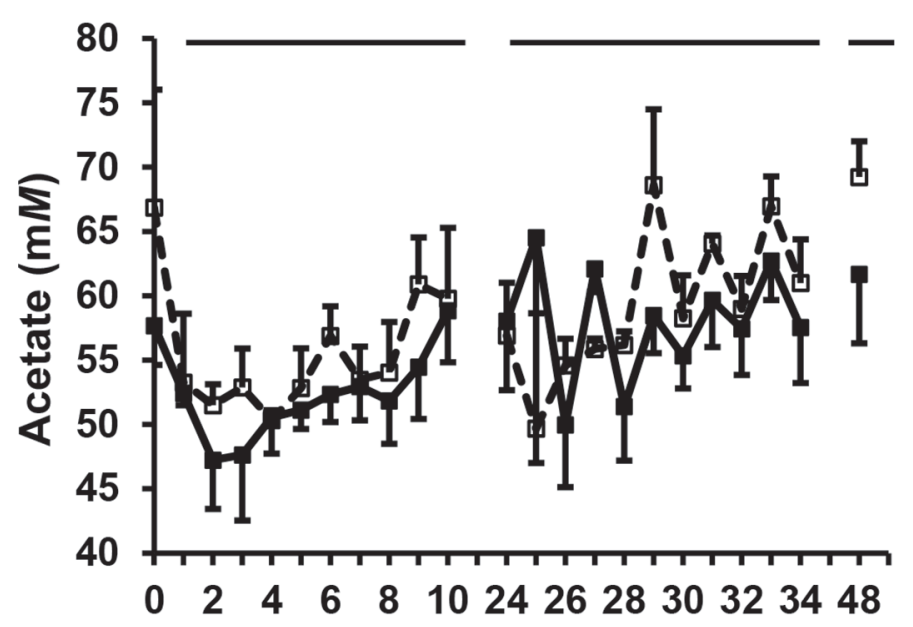

b

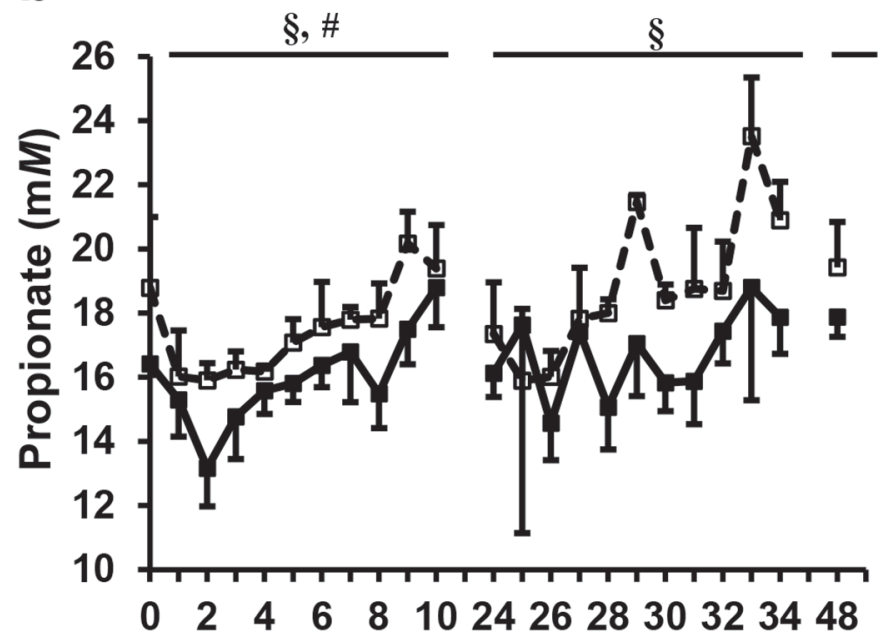

d

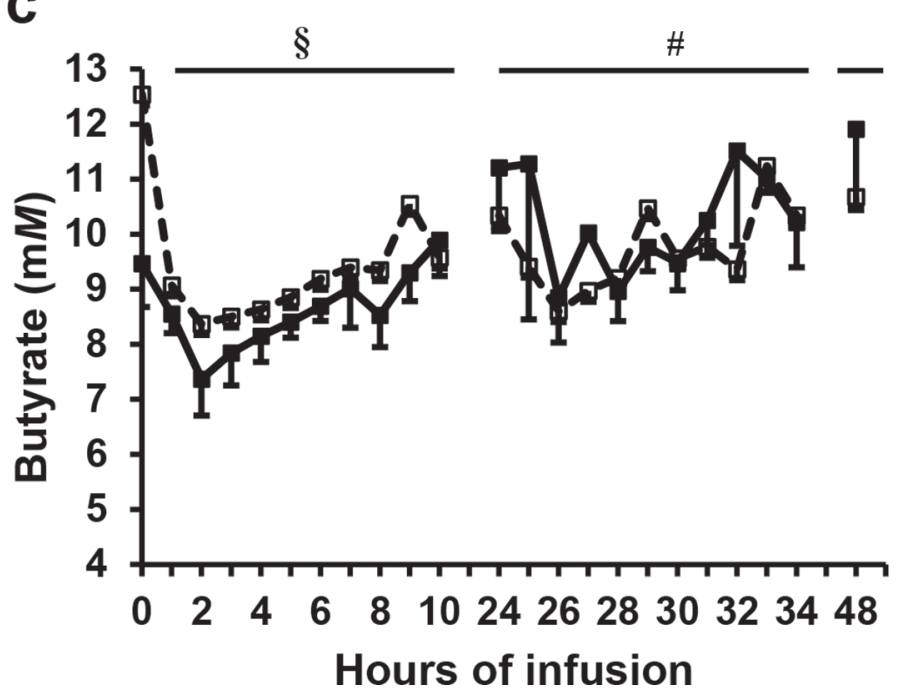

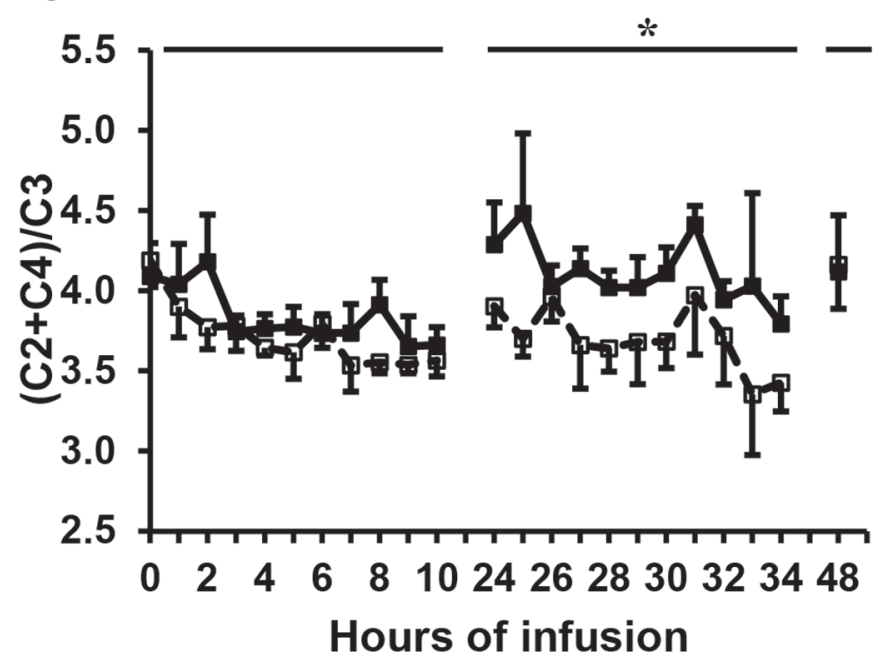

Figure 2. Ruminal (a) acetate, (b) propionate, and (c) butyrate concentrations and (d) the (acetate + butyrate)/propionate ratio of cows intravenously infused with lipofundin (LIPO, - $)$ or saline $(\mathrm{CON}, \square)$ for $48 \mathrm{~h}$. Data are shown as mean \pm SE. For each time interval, $*$ indicates $P_{\text {infusion }}<0.05, \S$ indicates $P_{\text {infusion }} \leq 0.10$, and \# indicates $P_{\text {time }} \leq 0.10$ (ANOVA). $P$-values for infusion $\times$ time, order, infusion $\times$ order, time $\times$ order, and infusion $\times$ time $\times$ order are presented in Supplemental Table S2 (https://doi.org/10.3168/jds.2017-14101). 
INTRAVENOUS LIPID INFUSION IN LATE-LACTATING HOLSTEINS

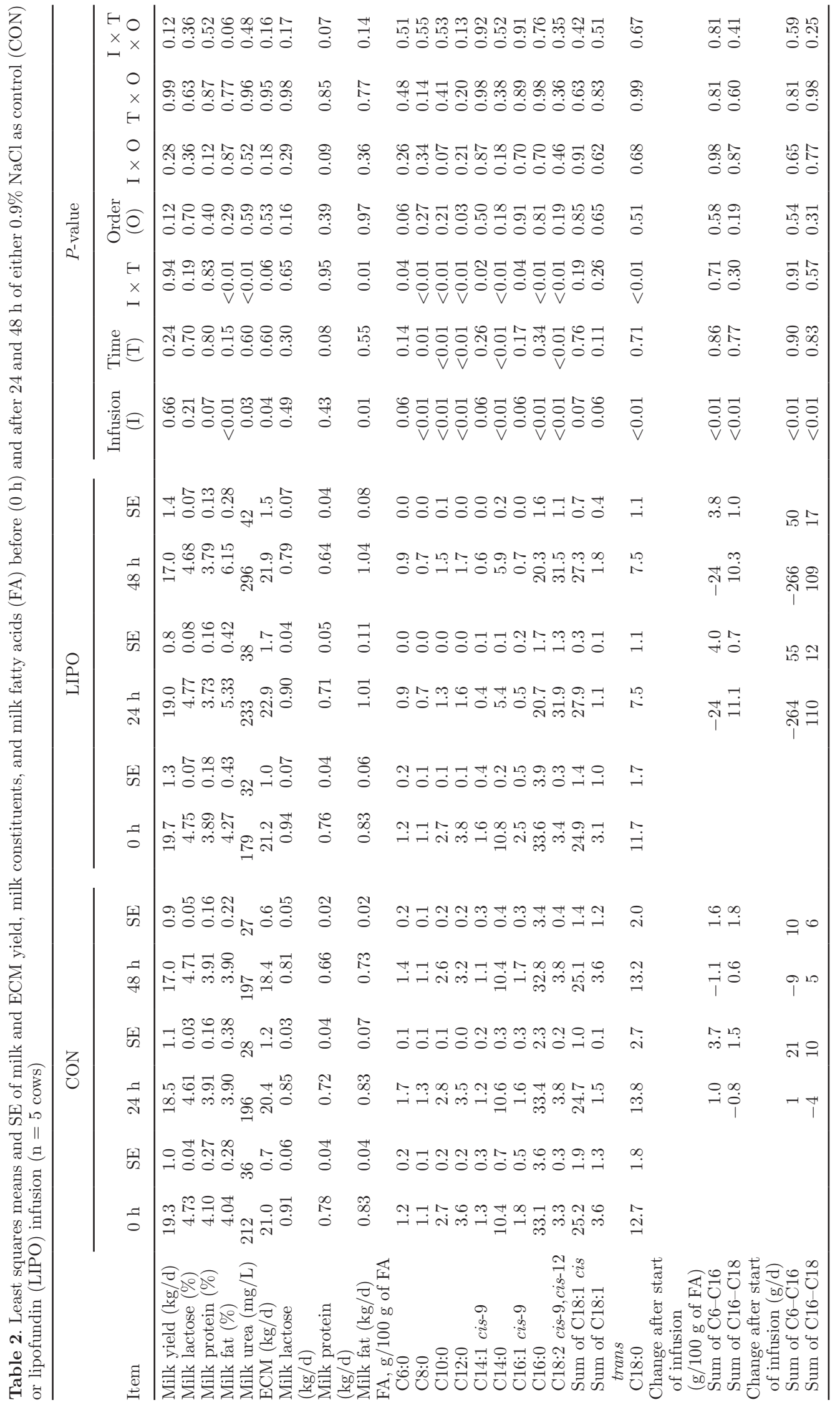



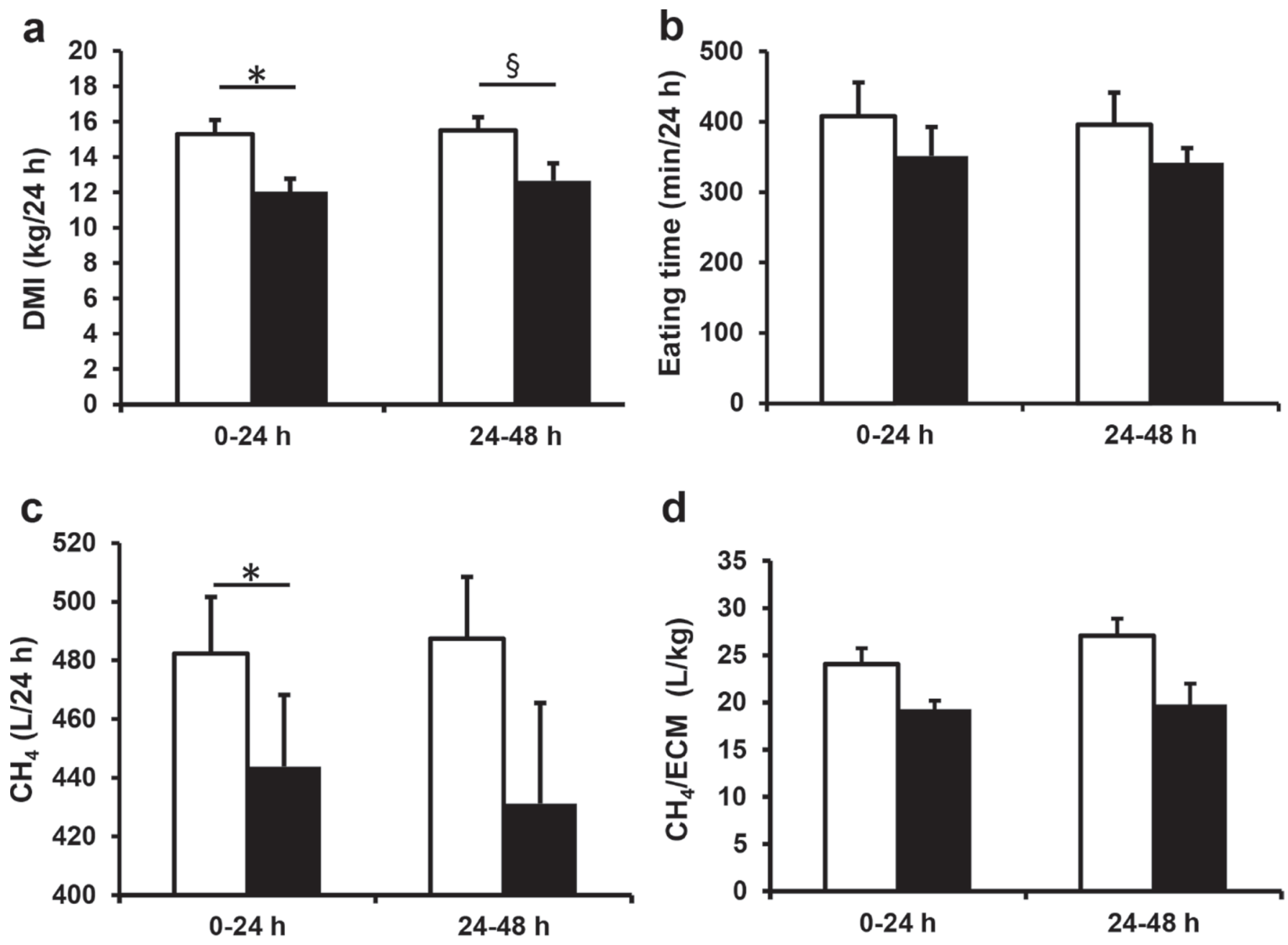

d

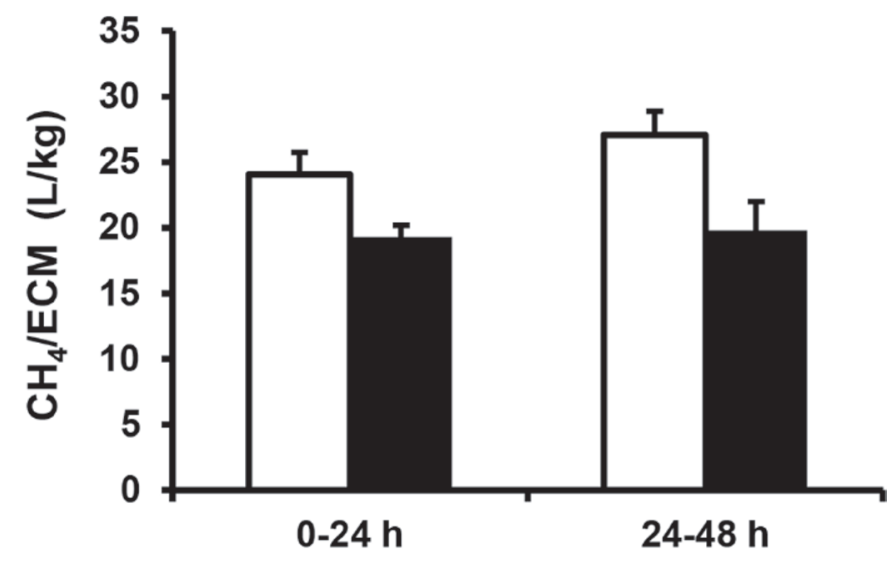

e

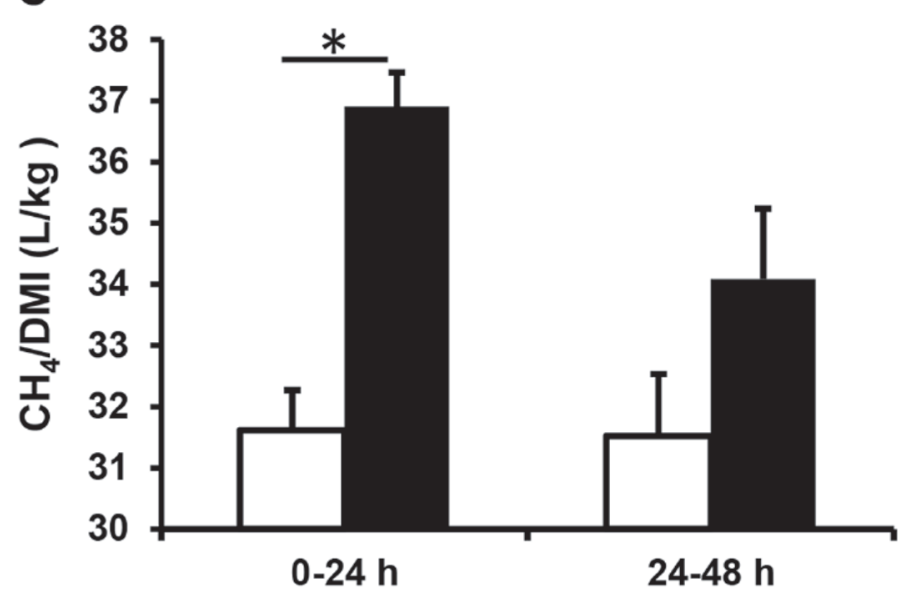

Hours of infusion

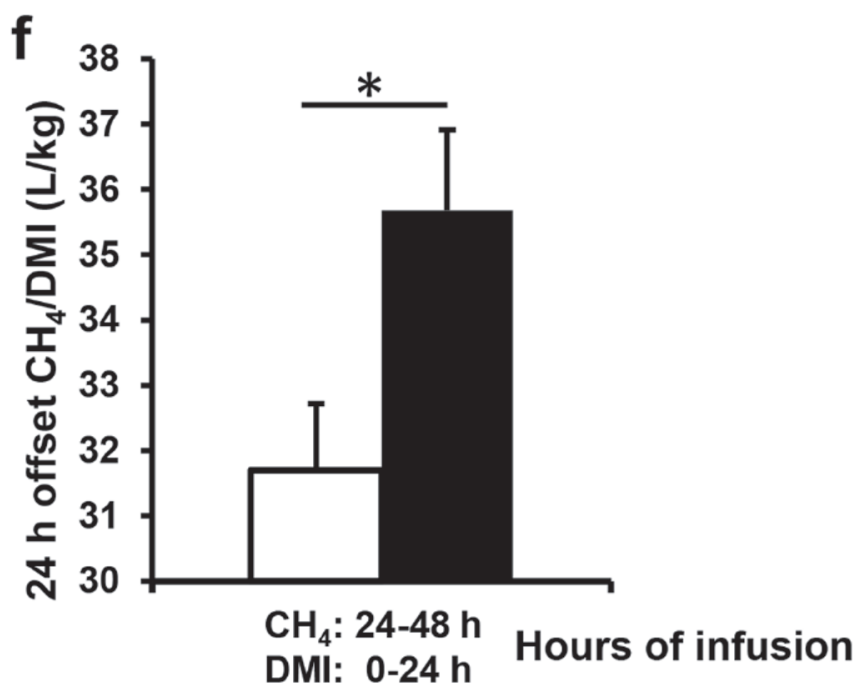

Figure 3. Daily (a) DMI, (b) eating time, (c) $\mathrm{CH}_{4}$ production, (d) $\mathrm{CH}_{4}$ per ECM yield, (e) $\mathrm{CH}_{4}$ per DMI, and (f) 24 h-offset $\mathrm{CH}_{4}$ yield of cows intravenously infused with lipofundin $(\mathrm{LIPO}, \mathbf{\square})$ or saline $(\mathrm{CON}, \square)$ for $48 \mathrm{~h}($ each $\mathrm{n}=5$ ). Data are shown as mean $\pm \mathrm{SE} ; *$ indicates $P<$ 0.05 and $\S$ indicates $P<0.1$ (Tukey-Kramer). (a) $P_{\text {infusion }}<0.01, P_{\text {time }}=0.68$. (b) $P_{\text {infusion }}=0.02, P_{\text {time }}=0.92$. (c) $P_{\text {infusion }}=0.01, P_{\text {time }}=0.93$. (d) $P_{\text {infusion }}=0.02, P_{\text {time }}=0.42$. (e) $P_{\text {infusion }}=0.03, P_{\text {time }}=0.22$. (f) $P_{\text {infusion }}=0.03$. $P$-values for infusion $\times$ time, order, infusion $\times$ order, time $\times$ order, and infusion $\times$ time $\times$ order are presented in Supplemental Table S2 (https://doi.org/10.3168/jds.2017-14101). 


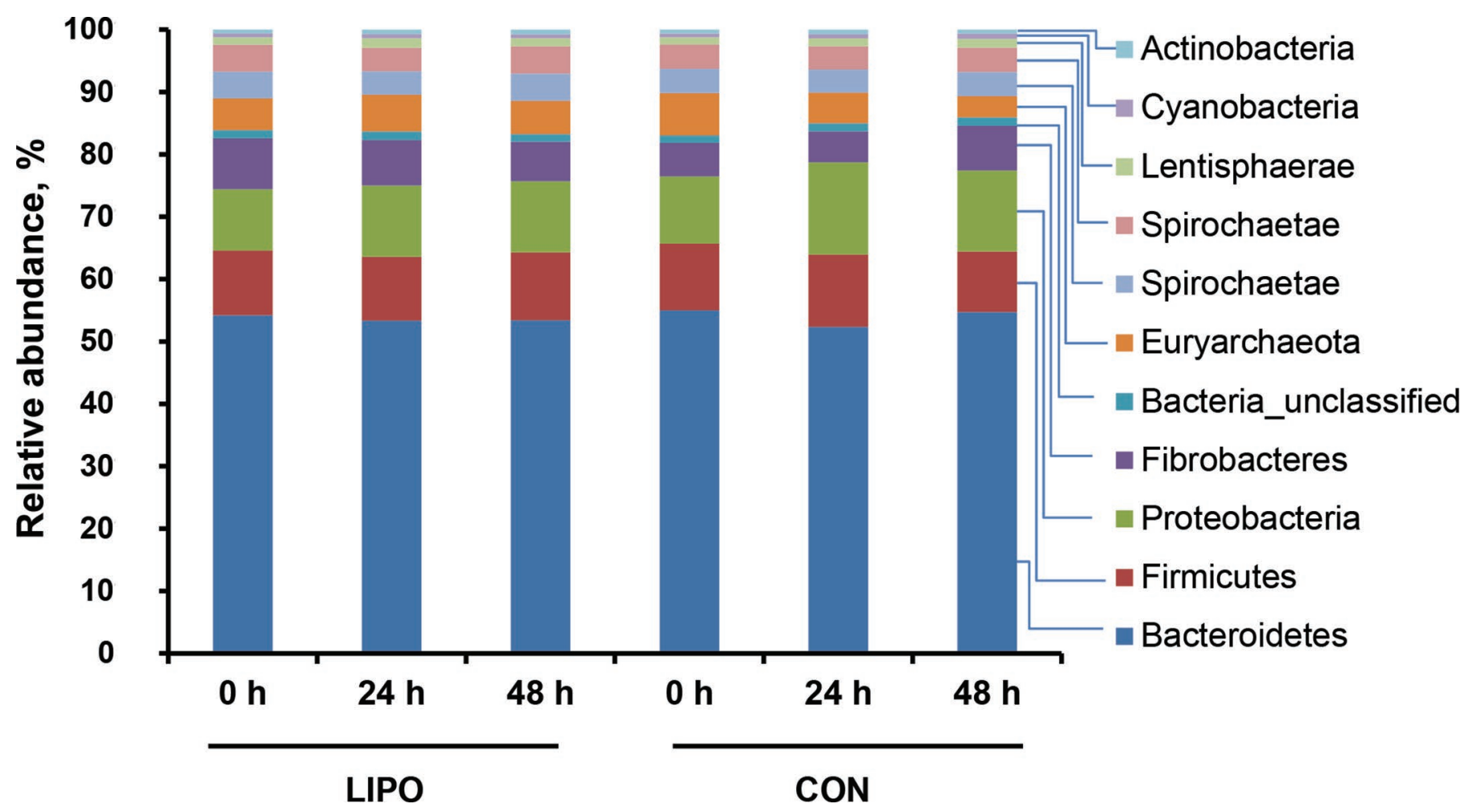

Figure 4. Mean prevalence of the 10 most abundant phyla as group means before $(0 \mathrm{~h})$ and after 24 and $48 \mathrm{~h}$ of either lipofundin (LIPO) or saline $(\mathrm{CON})$ infusion (each $\mathrm{n}=4$ ). Statistical evaluations of taxa relative abundances are presented in Table 3 and Supplemental Table S3 (https://doi.org/10.3168/jds.2017-14101). Color version available online.

the microbial composition were observed at the level of low abundant phyla represented by Chloroflexi (Table $3)$. At the genus level, 3 genera, specifically Ruminococcaceae_UCG-001, Succinivibrio, and Ruminiclostridium_9, were found to be less abundant in the rumen of LIPO-infused cows, whereas an unclassified genus of Bacteroidetes was more abundant compared with $\mathrm{CON}$ cows. However, the relative abundances of these genera did not significantly change from d 1 to d 2 of infusion.
The concentration of plasma serotonin, which is known to reduce rumen motility, increased with increasing time of infusion in both groups $\left(P_{\text {time }}=0.02\right)$ but was significantly higher with LIPO compared with CON infusion $\left(P_{\text {infusion }}<0.01\right.$; Figure 1f). In parallel to the lower DMI, COX was reduced and FOX increased (each: $P_{\text {infusion }}<0.05$ ) during LIPO relative to CON infusion (Figures 5a and b), whereas EE was comparable between $\mathrm{CON}$ - and LIPO-infused animals $\left(P_{\text {infusion }}=\right.$

Table 3. Mean and differential relative abundances of taxa in the rumen of cows receiving intravenous lipofundin (LIPO) or saline (CON) infusions $(n=4$ cows $)$

\begin{tabular}{|c|c|c|c|c|}
\hline Taxon & $\begin{array}{c}\text { Mean relative } \\
\text { abundance }(\%)\end{array}$ & $\begin{array}{l}\text { Fold change } \\
\text { CON vs. LIPO }\end{array}$ & $\begin{array}{l}\text { Nominal } \\
P \text {-value }\end{array}$ & $\begin{array}{l}\text { Adjusted } \\
P \text {-value }\end{array}$ \\
\hline \multicolumn{5}{|l|}{ Phylum } \\
\hline Chloroflexi & 0.88 & -1.26 & $<0.01$ & $<0.05$ \\
\hline \multicolumn{5}{|l|}{ Genus $^{2}$} \\
\hline Ruminococcaceae_UCG-001 & 0.05 & 2.42 & $<0.01$ & $<0.01$ \\
\hline Bacteroidetes_BD2-2_unc. & 0.05 & -1.90 & $<0.01$ & $<0.01$ \\
\hline Succinivibrio & 0.24 & 1.91 & $<0.01$ & $<0.01$ \\
\hline Ruminiclostridium_9 & 0.03 & 2.58 & $<0.01$ & $<0.01$ \\
\hline
\end{tabular}

${ }^{1}$ Based on Benjamini-Hochberg corrections for multiple testing. Adjusted $P$-values $<0.05$ were considered to be statistically significant. Additional taxa comparisons exceeding the threshold value are reported in Supplemental Table S3 (https://doi.org/10.3168/jds.2017-14101).

${ }^{2}$ The lowest possible level of classification is given, followed by "unclassified" (unc.). 
a

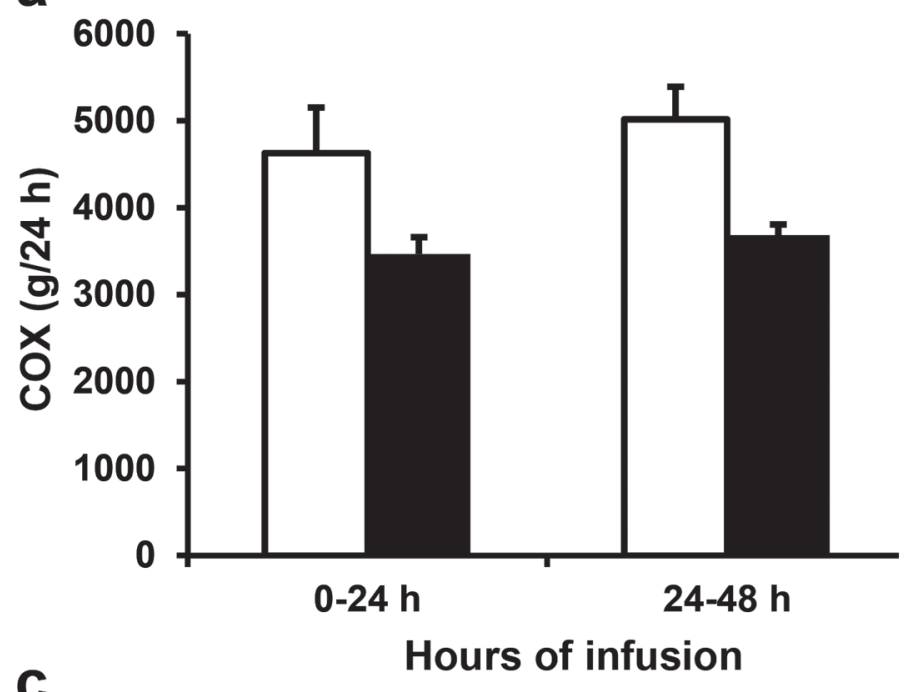

C

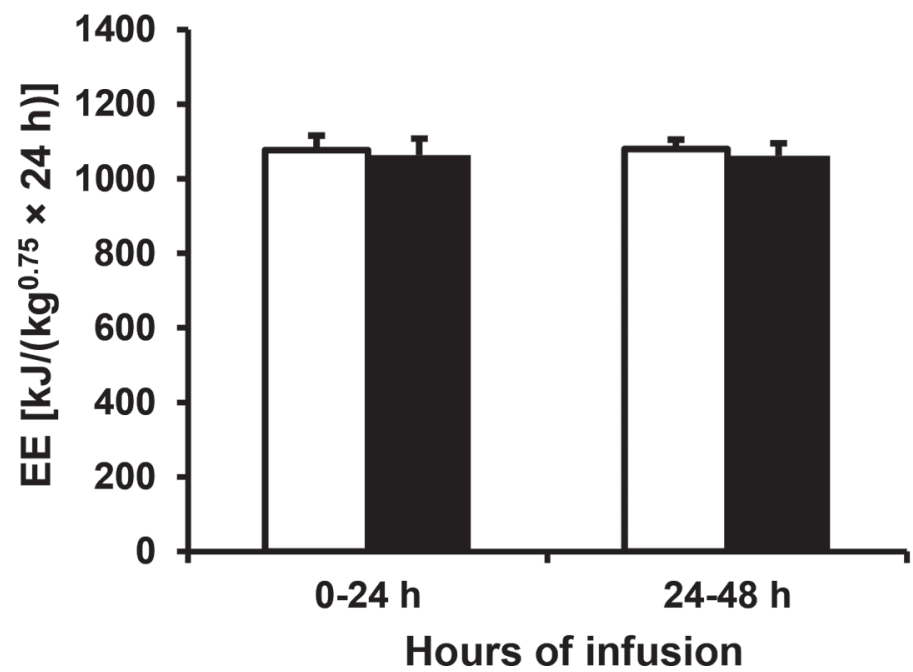

b

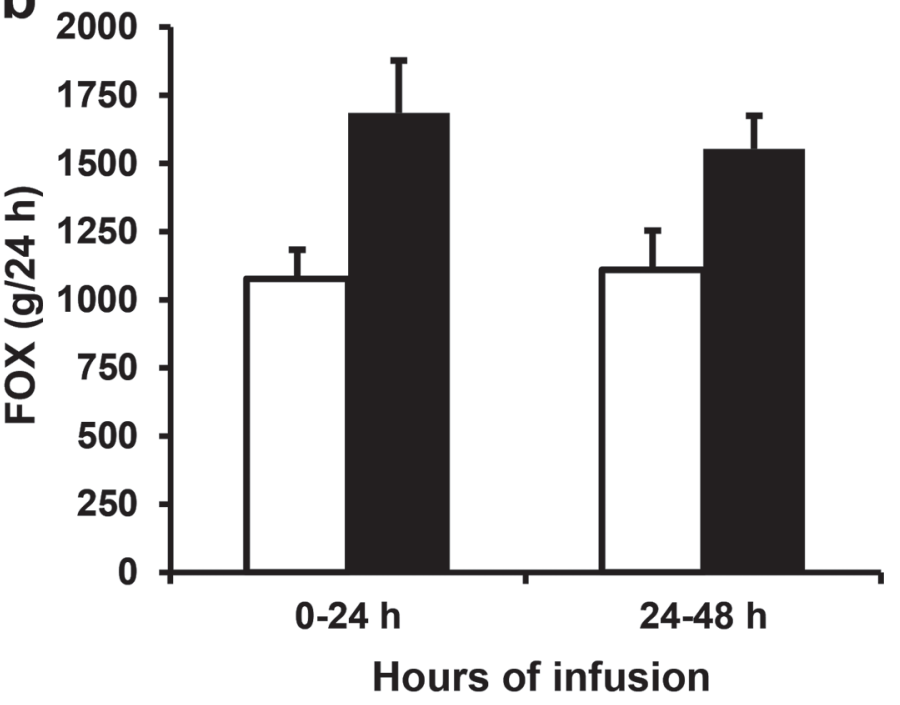

Figure 5. (a) Carbohydrate oxidation (COX), (b) fat oxidation (FOX), and (c) energy expenditure (EE) of cows intravenously infused with lipofundin $(\mathrm{LIPO}, \mathbf{\square})$ or saline $(\mathrm{CON}, \square)$ for $48 \mathrm{~h}$. Data are shown as mean $\pm \mathrm{SE}$. (a) $P_{\text {infusion }}=0.02, P_{\text {time }}=0.48$. (b) $P_{\text {infusion }}=0.04, P_{\text {time }}$ $=0.89$. (c) $P_{\text {infusion }}=0.38, P_{\text {time }}=0.99$. $P$-values for infusion $\times$ time, order, infusion $\times$ order, time $\times$ order, and infusion $\times$ time $\times$ order are presented in Supplemental Table S2 (https://doi.org/10.3168/jds.2017-14101).

0.38; Figure 5c). There was no change in COX, FOX, or EE from d 1 to d 2 of infusion.

\section{DISCUSSION}

\section{Plasma Metabolites}

Triglycerides intravenously infused to dairy cows are converted by lipases, resulting in the formation of free fatty acids and glycerol. The concentrations of TG and free fatty acids at plateau depend on multiple factors involving the concentration of the lipid emulsion, rate and duration of infusion, BW, lactation status, milk yield, and activities of lipase and fat oxidation enzymes. Intrajugular 20\% Intralipid infusion for $3 \mathrm{~h}$ increased plasma NEFA concentrations to $1,500 \mu M$ in late-lactating cows with a BW of $685 \mathrm{~kg}$ and a milk yield of $23 \mathrm{~L} / \mathrm{d}$ (Chelikani et al., 2003). Although cows investigated in the present study were comparable in stage of lactation and milk yield and weighted on average $100 \mathrm{~kg}$ less than cows in the Chelikani et al. (2003) study, the NEFA plateau of our cows reached only 380 to $400 \mu M$ after the second hour of infusion, which may be due to different infusion rates; however, Chelikani et al. (2003) provided no data on this. On the other hand, Pires et al. (2007) infused $0.1 \mathrm{~g}$ of $\mathrm{TG} / \mathrm{kg}$ of BW per hour to nonlactating, nongestating cows and reached an NEFA plateau at 300 to $370 \mu M$, which is 
comparable with the infusion rate of $0.15 \mathrm{~g}$ of $\mathrm{TG} / \mathrm{kg}$ of BW per hour and an NEFA plateau at 400 to 500 $\mu M$ observed in the present study. Continuous LIPO infusion lasting for 4 (Bareille and Faverdin, 1996) or 6 h (Chelikani et al., 2003) did not affect plasma BHB and glucose concentrations of cows that were 92 or 249 DIM, and our study extends these findings to a $48-\mathrm{h}$ continuous infusion period. Furthermore, when TG emulsion was administered for 20 to 30 min every $4 \mathrm{~h}$ throughout a 4-d fasting period of nonlactating cows, plasma BHB concentrations continuously increased over time (Mashek et al., 2005). The latter result likely was caused by the negative energy balance as TG infusions to early-lactating cows increased plasma BHB concentrations (Chelikani et al., 2003). The significant effect of order of infusion on plasma TG, NEFA, and glucose concentrations $\left(P_{\text {order}}\right.$; Supplemental Table S2, https:// doi.org/10.3168/jds.2017-14101) is not due to potential carryover effects, as higher values were observed in cows first receiving CON compared with cows first receiving LIPO. As CON infusion did not increase plasma TG, NEFA, and glucose concentrations, it seems that the 2 cows first receiving a CON infusion had intrinsically higher basal concentrations of these metabolites.

\section{Milk Yield and Constituents}

The ECM tended to decline from the preinfusion period to the end of infusion in CON cows only

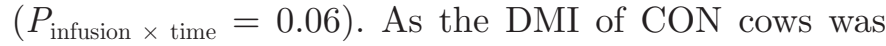
comparable between the day before chamber transfer and $\mathrm{d} 1$ and $\mathrm{d} 2$ of infusion, this effect cannot be caused by a reduction of DMI, which normally is observed when free-ranging cows are transferred into a respiration chamber. It rather appears that both LIPO and CON cows experienced a similar level of stress but that LIPO infusion compensated for the loss of ECM observed in CON cows. Percentage of milk protein tended to decrease with LIPO infusion, likely because of the decreased supply of rumen fermentable energy reducing microbial growth in the rumen. On the other hand, milk urea concentrations were greater in LIPO cows and increased over time in LIPO but not CON cows. It has been shown that feed restriction diminishes milk urea concentrations (Bjerre-Harpøth et al., 2012), indicating that the lower DMI of LIPO cows does not account for the observed increase in milk urea concentration. As LIPO infusion causes insulin resistance in dairy cows (Pires et al., 2007), it seems that AA catabolism predominates anabolism during LIPO treatment, thereby increasing milk urea levels.

Arterial fatty acid concentrations determine the uptake, synthesis, and desaturation of fatty acids by the mammary gland. The transfer efficiency of intrave- nously administered linoleic acid, the major fatty acid of the lipid emulsion, into milk of dairy cows on d 235 of lactation has been determined to be as high as $38 \%$ (Stamey Lanier et al., 2013). Accordingly, we found that the highest increase of MFA for $\mathrm{C} 18: 2$ cis-9, cis-12 and daily production of $\mathrm{C} 16$ plus $\mathrm{C} 18$ MFA increased with LIPO infusion. By contrast, the sum of daily produced de novo-synthesized MFA (sum of C6 to C16) decreased, suggesting inhibition of the de novo MFA synthesis and a sparing of acetate. However, saving acetate in milk fat synthesis could result in accumulating plasma acetate concentrations if the amount of acetate absorption from the rumen remains constant. However, contrary to our assumption, plasma acetate concentrations were not different from $\mathrm{CON}$ infusion on the first day but rather tended to be lower in LIPO than CON cows on the second day of infusion. This result might be due to the reduction in DMI decreasing the acetate absorption under the influence of LIPO treatment.

\section{Effect of Lipid Infusion on DMI}

It appears that the order of infusion had an effect on DMI $\left(P_{\text {order }}=0.05\right)$. However, any carryover effects can be excluded as the 3 cows first receiving LIPO had intrinsically higher DMI levels before infusion. The present study further showed that LIPO infusion reduced DMI, whereas Stocks and Allen (2014) recently reported that a 24 -h intravenous lipid infusion did not affect DMI of dairy cows that were 81 to 252 DIM. Comparable with our results, intravenous infusion of a 20\% TG emulsion has been reported to reduce DMI in cows of 92 DIM (Bareille and Faverdin, 1996) and 249 DIM (Chelikani et al., 2003). The LIPO-induced reduction in DMI was attributed primarily to a reduction in eating time, whereas cows infused with TG on d 92 postpartum responded with a reduction in eating rate but not with an altered eating time (Bareille and Faverdin, 1996). It is highly likely that the anorexic effect of TG is elicited by free fatty acids resulting from TG cleavage, as intravenous long-chain fatty acid infusion to sheep reduced DMI during infusion (Vandermeerschen-Doizé and Paquay, 1984). Whether long-chain fatty acids act directly at anorexic centers in the brain, trigger for anorexic signaling through hepatic $\beta$-oxidation (Friedman et al., 1999), or both remains speculative. It seems that fatty acids accumulating with LIPO infusion are primarily metabolized by extrahepatic organs as the infusion of tallow emulsion did not affect total or peroxisomal oxidation in liver homogenates (Mashek et al., 2005). Therefore, the anorexic response elicited by LIPO seems not to be triggered by hepatic $\beta$-oxidation pathways. Moreover, our recent finding elucidating the dynamic association 
between whole-body fat oxidation and feed intake of late-lactating dairy cows rather shows that feed intake affects FOX but that FOX has only a minor effect on feed intake (Derno et al., 2013). The increase in FOX and the reduction in DMI reducing COX is likely the attempt of the host to maintain energy homeostasis, as indicated by a constant EE during LIPO treatment.

\section{Effect of Lipid Infusion on Fermentation Characteristics, Bacteria Structure, and $\mathrm{CH}_{4}$ Production}

It is important to note that DMI during LIPO treatment declined to approximately $80 \%$ relative to $\mathrm{CON}$ animals on both days of infusion. The reduction of feed intake is usually accompanied by prolonged digesta retention time in the rumen-intestinal tract, an increased molar acetate:propionate ratio in the rumen (Voigt et al., 2000), and an increase in $\mathrm{CH}_{4}$ yield (Benchaar et al., 1998). We found increased plasma serotonin concentrations with LIPO infusion, and intravenous application of serotonin has been shown to induce hypomotility in the rumen (Plaza et al., 1996), indicating that a LIPOinduced increase in serotonin may account for a longer digesta retention time in the rumen. A longer retention time would intensify fiber fermentation, resulting in a greater (acetate + butyrate)/propionate ratio. Accordingly, the ratio was found to be significantly higher in LIPO cows than in CON cows on $\mathrm{d} 2$ but not on $\mathrm{d} 1$ or at $48 \mathrm{~h}$ of infusion. Thus, it seems that the reduction in DMI accounts for the increased molar (acetate + butyrate)/propionate proportion and the greater $\mathrm{CH}_{4}$ yield in LIPO cows. However, the transient increase in the (acetate + butyrate)/propionate ratio apparently depends on the duration of infusion and the time during the 24-h cycle and was surprisingly not due to an increase in rumen acetate concentrations, as described for ruminants on a reduced nutrition level (Voigt et al., 2000). Nevertheless, one genus among Bacteroidetes (Bacteroidetes_BD2-2) producing mainly acetate was upregulated in LIPO cows. There is evidence that the relative abundance of Bacteroidetes is affected by both fasting (Crawford et al., 2009) and intravenous lipid supply (Hodin et al., 2012). Hodin et al. (2012) showed that the portion of Bacteroidetes in total bacteria increased when rats received an infusion of total parenteral nutrition solution containing $20 \%$ Intralipid. However, these effects on the level of phylum were observed after an infusion period of $14 \mathrm{~d}$, whereas the differences induced by a 2 -d treatment between $\mathrm{CON}$ and LIPO in the current study were visible only at the Bacteroidetes_BD2-2 genus. The total relative abundance of Bacteroidetes did not change significantly between LIPO and CON cows.
The increased (acetate + butyrate)/propionate ratio in LIPO cows was primarily caused by a trend toward declining rumen propionate concentrations in LIPO cows. This finding can be at least in part attributed to the lower relative abundance of Succinivibrio because this genus is known to facilitate ruminal starch digestion and propionate formation (Hespell, 1992). Interestingly, relative gene abundance of Succinivibrio was found to be positively correlated with the relative abundance of Methanobrevibacter in cows (Liu et al., 2017) and with $\mathrm{CH}_{4}$ yield in sheep (Kamke et al., 2017), whereas Succinivibrionaceae were reduced, but the Methanobrevibacter gottschalkii clade increased in feed-restricted cattle (McCabe et al., 2015). Furthermore, the fibrolytic species Ruminococcaceae and Ruminiclostridium_9 were less abundant in LIPO than CON cows, and, comparably, intravenous infusion of a lipid emulsion reduced at least the relative abundance of Clostridiaceae in the intestine of neonatal piglets (Lavallee et al., 2016). Both Ruminococcaceae and Ruminiclostridium_9 degrade lignocellulose and produce $\mathrm{H}_{2}$, suggesting that the intermediary $\mathrm{H}_{2}$ production, the precondition for $\mathrm{CH}_{4}$ synthesis, and interspecies $\mathrm{H}_{2}$ transfer were negatively affected in LIPO cows. Thus, the lower relative abundances of Succinivibrio, Ruminococcaceae, and Ruminiclostridium_9 may explain the trend toward reduced rumen propionate concentrations and lower $\mathrm{CH}_{4}$ production of LIPO cows. However, differences in the relative abundance of methanogens between treatments could not be determined.

In conclusion, our study demonstrates that increased concentrations of circulating lipids and long-chain fatty acids increase the serotonin tone, presumably leading to hypomotility of the rumen, reduction in DMI, and, consequently, $\mathrm{CH}_{4}$ production in late-lactating dairy cows. Although DMI was reduced to the same extent on both days of LIPO infusion, $\mathrm{CH}_{4}$ yield was $8 \%$ lower on d 2 compared with d 1 of LIPO infusion, indicating that $\mathrm{CH}_{4}$ yield on $\mathrm{d} 1$ was still affected by feed consumed in the $24-\mathrm{h}$ preinfusion period. However, the greater 24-h offset $\mathrm{CH}_{4}$ yield of LIPO cows compared with CON cows suggests that the lower intake rather than the intravenously administered TG per se leads to an increased $\mathrm{CH}_{4}$ yield. This result led us to conclude that the lower $\mathrm{CH}_{4}$ yield of cows that mobilized high fat compared with less fat (Bielak et al., 2016) was not due to higher NEFA concentration in early lactation. Furthermore, the tendency for lower ruminal propionate concentration as well as relative abundances of Succinivibrio, Ruminococcaceae, and Ruminiclostridium in the rumen indicate that less intermediary $\mathrm{H}_{2}$ is formed with reduced DMI or LIPO infusion, respectively. To distinguish between the effect of DMI and in vitro LIPO infusion, future pair-feeding experiments with longer 
infusion times than applied in the current study need to be performed to test whether $\mathrm{CH}_{4}$ yield decreases below the level of pair-fed controls.

\section{ACKNOWLEDGMENTS}

We thank C. Arlt, S. Wiese, M. Althaus, and the staff at the "Tiertechnikum" and the cattle experimental unit at the Leibniz Institute for Farm Animal Biology (FBN; Dummerstorf, Germany) for animal care and handling, sample collection, and sample preparation.

\section{REFERENCES}

Bareille, N., and P. Faverdin. 1996. Lipid metabolism and intake behavior of dairy cows: Effects of intravenous lipid and beta-adrenergic supplementation. J. Dairy Sci. 79:1209-1220.

Benchaar, C., J. Rivest, C. Pomar, and J. Chiquette. 1998. Prediction of methane production from dairy cows using existing mechanistic models and regression equations. J. Anim. Sci. 76:617-627.

Bielak, A., M. Derno, A. Tuchscherer, H. M. Hammon, A. Susenbeth, and B. Kuhla. 2016. Body fat mobilization in early lactation influences methane production of dairy cows. Sci. Rep. 6:28135.

Bjerre-Harpøth, V., N. C. Friggens, V. M. Thorup, T. Larsen, B. M. Damgaard, K. L. Ingvartsen, and K. M. Moyes. 2012. Metabolic and production profiles of dairy cows in response to decreased nutrient density to increase physiological imbalance at different stages of lactation. J. Dairy Sci. 95:2362-2380.

Börner, S., E. Albrecht, C. Schäff, S. Hacke, U. Kautzsch, M. Derno, H. M. Hammon, M. Röntgen, H. Sauerwein, and B. Kuhla. 2013a. Reduced AgRP activation in the hypothalamus of cows with high extent of fat mobilization after parturition. Gen. Comp. Endocrinol. 193:167-177.

Börner, S., M. Derno, S. Hacke, U. Kautzsch, C. Schäff, S. Thanthan, H. Kuwayama, H. M. Hammon, M. Röntgen, R. Weikard, C. Kühn, A. Tuchscherer, and B. Kuhla. 2013b. Plasma ghrelin is positively associated with body fat, liver fat and milk fat content but not with feed intake of dairy cows after parturition. J. Endocrinol. 216:217-229.

Chelikani, P. K., D. H. Keisler, and J. J. Kennelly. 2003. Response of plasma leptin concentration to jugular infusion of glucose or lipid is dependent on the stage of lactation of Holstein cows. J. Nutr. 133:4163-4171.

Chilliard, Y., C. Martin, J. Rouel, and M. Doreau. 2009. Milk fatty acids in dairy cows fed whole crude linseed, extruded linseed, or linseed oil, and their relationship with methane output. J. Dairy Sci. 92:5199-5211.

Chwalibog, A., K. Jensen, and G. Thorbek. 1996. Oxidation of nutrients in bull calves treated with beta-adrenergic agonists. Arch. Tierernahr. 49:255-261.

Crawford, P. A., J. R. Crowley, N. Sambandam, B. D. Muegge, E. K. Costello, M. Hamady, R. Knight, and J. I. Gordon. 2009. Regulation of myocardial ketone body metabolism by the gut microbiota during nutrient deprivation. Proc. Natl. Acad. Sci. USA 106:11276-11281.

Derno, M., G. Nürnberg, P. Schön, A. Schwarm, M. Röntgen, H. M. Hammon, C. C. Metges, R. M. Bruckmaier, and B. Kuhla. 2013. Short-term feed intake is regulated by macronutrient oxidation in lactating Holstein cows. J. Dairy Sci. 96:971-980.

Dijkstra, J., O. Oenema, J. W. van Groenigen, J. W. Spek, A. M. van Vuuren, and A. Bannink. 2013. Diet effects on urine composition of cattle and $\mathrm{N}_{2} \mathrm{O}$ emissions. Animal 7(Suppl. 2):292-302.

Edgar, R. C., B. J. Haas, J. C. Clemente, C. Quince, and R. Knight. 2011. UCHIME improves sensitivity and speed of chimera detection. Bioinformatics 27:2194-2200.
Friedman, M. I., R. B. Harris, H. Ji, I. Ramirez, and M. G. Tordoff. 1999. Fatty acid oxidation affects food intake by altering hepatic energy status. Am. J. Physiol. 276:R1046-R1053.

Garnsworthy, P. C., J. Craigon, J. H. Hernandez-Medrano, and N. Saunders. 2012. Variation among individual dairy cows in methane measurements made on farm during milking. J. Dairy Sci. 95:3181-3189.

Harris, J. K., K. C. El Kasmi, A. L. Anderson, M. W. Devereaux, S. A. Fillon, C. E. Robertson, B. D. Wagner, M. J. Stevens, N. R. Pace, and R. J. Sokol. 2014. Specific microbiome changes in a mouse model of parenteral nutrition associated liver injury and intestinal inflammation. PLoS One 9:e110396.

Hespell, R. B. 1992. The genera Succinivibrio and Succinimonas. Pages 3979-3982 in The Prokaryotes. Springer, Berlin, Germany.

Hodin, C. M., R. G. Visschers, S. S. Rensen, B. Boonen, S. W. Olde Damink, K. Lenaerts, and W. A. Buurman. 2012. Total parenteral nutrition induces a shift in the Firmicutes to Bacteroidetes ratio in association with Paneth cell activation in rats. J. Nutr. 142:2141-2147.

Hugerth, L. W., H. A. Wefer, S. Lundin, H. E. Jakobsson, M. Lindberg, S. Rodin, L. Engstrand, and A. F. Andersson. 2014. DegePrime, a program for degenerate primer design for broad-taxonomic-range PCR in microbial ecology studies. Appl. Environ. Microbiol. 80:5116-5123.

Johnson, K. A., R. L. Kincaid, H. H. Westberg, C. T. Gaskins, B. K. Lamb, and J. D. Cronrath. 2002. The effect of oilseeds in diets of lactating cows on milk production and methane emissions. J. Dairy Sci. 85:1509-1515.

Kamke, J., P. Soni, Y. Li, S. Ganesh, W. J. Kelly, S. C. Leahy, W. Shi, J. Froula, E. M. Rubin, and G. T. Attwood. 2017. Gene and transcript abundances of bacterial type III secretion systems from the rumen microbiome are correlated with methane yield in sheep. BMC Res. Notes 10:367.

Kozich, J. J., S. L. Westcott, N. T. Baxter, S. K. Highlander, and P. D. Schloss. 2013. Development of a dual-index sequencing strategy and curation pipeline for analyzing amplicon sequence data on the MiSeq Illumina sequencing platform. Appl. Environ. Microbiol. 79:5112-5120

Kristensen, N. B., S. G. Pierzynowski, and A. Danfaer. 2000. Net portal appearance of volatile fatty acids in sheep intraruminally infused with mixtures of acetate, propionate, isobutyrate, butyrate, and valerate. J. Anim. Sci. 78:1372-1379.

Lavallee, C. M., J. A. R. MacPherson, M. Zhou, Y. Gao, P. R. Wizzard, P. W. Wales, J. M. Turner, and B. P. Willing. 2016. Lipid emulsion formulation of parenteral nutrition affects intestinal microbiota and host responses in neonatal piglets. J. Parenter. Enteral. Nutr. 41:1301-1309.

Leonhardt, M., and W. Langhans. 2004. Fatty acid oxidation and control of food intake. Physiol. Behav. 83:645-651.

Lerch, S., J. A. Pires, C. Delavaud, K. J. Shingfield, D. Pomiès, B. Martin, Y. Chilliard, and A. Ferlay. 2015. Rapeseed or linseed in dairy cow diets over 2 consecutive lactations: Effects on adipose fatty acid profile and carry-over effects on milk fat composition in subsequent early lactation. J. Dairy Sci. 98:1005-1018.

Liu, C., Q. Meng, Y. Chen, M. Xu, M. Shen, R. Gao, and S. Gan. 2017. Role of age-related shifts in rumen bacteria and methanogens in methane production in cattle. Front. Microbiol. 8:1563.

Love, M. I., W. Huber, and S. Anders. 2014. Moderated estimation of fold change and dispersion for RNA-seq data with DESeq2. Genome Biol. 15:550.

Machmüller, A., and M. Kreuzer. 1999. Methane suppression by coconut oil and associated effects on nutrient and energy balance in sheep. Can. J. Anim. Sci. 79:65-72.

Martin, C., J. Rouel, J. P. Jouany, M. Doreau, and Y. Chilliard. 2008. Methane output and diet digestibility in response to feeding dairy cows crude linseed, extruded linseed, or linseed oil. J. Anim. Sci. 86:2642-2650.

Mashek, D. G., S. J. Bertics, and R. R. Grummer. 2005. Effects of intravenous triacylglycerol emulsions on hepatic metabolism and blood metabolites in fasted dairy cows. J. Dairy Sci. 88:100-109. 
McCabe, M. S., P. Cormican, K. Keogh, A. O'Connor, E. O'Hara, R. A. Palladino, D. A. Kenny, and S. M. Waters. 2015. Illumina MiSeq Phylogenetic Amplicon Sequencing shows a large reduction of an uncharacterised Succinivibrionaceae and an increase of the Methanobrevibacter gottschalkii clade in feed restricted cattle. PLoS One 10:e0133234.

Naumann, C., and R. Bassler. 2006. Die Chemische Untersuchung von Futtermitteln. VDLUFA Verlag, Darmstadt, Germany.

Pires, J. A., A. H. Souza, and R. R. Grummer. 2007. Induction of hyperlipidemia by intravenous infusion of tallow emulsion causes insulin resistance in Holstein cows. J. Dairy Sci. 90:2735-2744.

Plaza, M. A., M. P. Arruebo, and M. D. Murillo. 1996. 5-Hydroxytryptamine induces forestomach hypomotility in sheep through 5-HT4 receptors. Exp. Physiol. 81:781-790.

Ryan, J. P. 1980. Determination of volatile fatty acids and some related compounds in ovine rumen fluid, urine, and blood plasma, by gas-liquid-chromatography. Anal. Biochem. 108:374-384.

Schloss, P. D., S. L. Westcott, T. Ryabin, J. R. Hall, M. Hartmann E. B. Hollister, R. A. Lesniewski, B. B. Oakley, D. H. Parks, and C. J. Robinson. 2009. Introducing mothur: Open-source, platform- independent, community-supported software for describing and comparing microbial communities. Appl. Environ. Microbiol. 75:7537-7541.

Stamey Lanier, J., J. K. Suagee, O. Becvar, and B. A. Corl. 2013. Mammary uptake of fatty acids supplied by intravenous triacylglycerol infusion to lactating dairy cows. Lipids 48:469-479.

Stocks, S. E., and M. S. Allen. 2014. Effects of lipid and propionic acid infusions on feed intake of lactating dairy cows. J. Dairy Sci. 97:2297-2304.

Stracke, J., W. Otten, A. Tuchscherer, B. Puppe, and S. Düpjan. 2017. Serotonin depletion induces pessimistic-like behavior in a cognitive bias paradigm in pigs. Physiol. Behav. 174:18-26.

Vandermeerschen-Doizé, F., and R. Paquay. 1984. Effects of continuous long-term intravenous infusion of long-chain fatty acids on feeding behaviour and blood components of adult sheep. Appetite 5:137-146.

Voigt, J., W. R. Jentsch, S. Kuhla, H. D. Matthes, and M. Derno. 2000. Rumen fermentation and retention time of the digesta in growing cattle of the breeds Black-White Dairy Cattle, Galloway, and Highland. Arch. Tierzucht 43:609-620. 